\title{
War Journalism and Vietnam Veterans
}

\author{
Alexander Nguyen ${ }^{1}$ \\ ${ }^{1}$ Carnegie Vanguard High School, Houston, Texas, USA
}

\section{ABSTRACT}

Occurring as a major conflict of the Cold War, the Vietnam War is perhaps the most memorable modern war in the nation's memory. This project has goals to study the interactions between press and the soldiers of this war, to understand the impact of the press during this time. The question leading this project is "Did the war journalism in Vietnam have an impact on the morale of American soldiers?" To investigate this, the researcher conducted surveys, interviews, and watched past CSPAN interviews to collect both broad and detailed data based on questions that would inquire into their interactions with press overall. The researcher found that overall, the morale of soldiers during the time were unaffected by the press. However, the number of people interviewed along with the amount of data gathered from the recorded interviews may have not been sufficient to accurately draw such a conclusion. These results allow for an understanding of the new form of television and radio press during the war, as well as a way to draw connections between the press of this war and others in terms of interactions of press.

\section{Introduction}

In today's political climate, the media and press has become a very important aspect of conversations throughout America. This phenomenon is, without a doubt, due to the wide availability of mass media and technology such as television, newspapers, radio, and the internet creating a dominating network of news cycles and editorial pieces. Their significance reflects the many biases of the American parties of the present day, but this is not the first timed media has played so heavily into the political biases of the public and their opinions. Press often plays a major part during wartime, and often "the press holds unparalleled power-the power to decide what the war means." This is clearly seen in the thousands of anti-war pieces written and recorded by both newspaper journalists and this new breed of TV journalist that would pop up during the Vietnam War. The different sorts of news would end up making a clear indentation onto Americans throughout the country, and the Vietnam War's unpopularity would largely come about due to the massive amounts of war journalism that occurred during the time. However, when researching war journalism, no researcher speaks extensively of the relationship between the war journalism and the soldiers themselves, who were fighting the war, and whether or not their thoughts and ideas on the war would end up impacting the direction and morale of the armed forces themselves. The researcher strives to do so in this paper by using a combination of a quantitative survey and a qualitative interview-based approach, as to understand both the broad opinions and experiences of soldiers and their interactions with press and media.

\section{Literature Review}

The Vietnam War is perhaps one of the most controversial as well as one of the largest scale wars that is still fresh in the memories of Americans. Nearly 9 million men and women served in the army during the war and about 3.4 million were deployed into the region. This was also the first televised war, where the average Americans could really experience the war visually from the living rooms of their homes. The new heavy press influence created a new essentiality for embedded journalism, which is any journalist embedded or placed into a military unit, opening up many new 
interactions between the soldier and the citizen. However, the middleman of the journalist and his or her experiences are rarely ever given attention, especially the interactions between the journalist and the soldier. Because this interaction is rarely ever discussed, it should be researched whether the morale of soldiers was affected by the journalists. During the most intense period of the Vietnam War, from 1965 to 1975, soldiers most likely had a negative relationship with and hostility towards journalists, due to the general hatred that the soldiers and the very unpopular war received as well as the suspected revealing of highly sensitive information through televised events, making their life harder. Perhaps a study into this very relationship between the press and the soldiers themselves would allow for a clear connection to be drawn. The trends in methodology, research question, and understanding of this topic and topics like it are quite similar as this topic is largely unanalyzed, and with the few that are, historical research and subjective, interview and survey-based analysis is presented. The research found is largely about how the journalism in Vietnam affected the people back in the United States. This research also recounts of the tales of military photographers which were present in Vietnam, but also including how war reporting in general is shaped today as well as then. This research in particular will add to the field of history by expanding and evaluating the perspective of the soldier him or herself, considering how the people sent to fight reacted to how they were documented, which was and still is rarely ever understood. It can also be used to draw parallels between soldiers from this war and past wars without television reporting, and future wars where even television has become more obsolete.

One theme commonly found in the subject of war journalism is how journalists framed wars and how they transmitted information about the wars to the American people. Through historical analysis, some researchers have found that most war journalism cannot be taken completely as objective truth as a lot of journalists further back were biased towards the war because of a strong sense of patriotism, while now, most are more towards painting the war in a bad light due to some immorality about giving the war positive exposure. McLaughlin (2016) writes about how even the information and objectivity of war reporting can be quite questionable, citing multiple examples of reporting when, even as far back as the Mexican-American war, reporters were showing bias for or against the war, whether the reason was the fact that they were part of the fight, or they held qualms against the morality of praising the death of other people. As the present has approached, this trend has moved towards a more sentimental and moral type of reporting where wars are seen through a much more emotional, but at the same time much less impartial, lens. This morality the journalists hold to such pride is researched by Sparre (2000), who describes the many different codes and moral rules that journalists must follow when reporting war, including that of disapproval of bloodshed and the duty they have to provide credible and responsible amounts of information to the public.

A second theme found on reports, this time more specifically on the subject of the Vietnam War and journalism's impact, is the perception of the Vietnam War, which has been quite divisive among some researchers. Through historical analysis of the reporting on current events of the time, some researchers have found that the American press, and by extension, the American public, was largely cognizant of the rising involvement of the US Army in the conflict in Vietnam, even as President Lyndon B. Johnson fought to hide it from the public as to not arouse any concern or backlash. As Proctor found, while the press was not as invested before 1964, they became invested as the events of the Gulf of Tonkin unfolded. He found that while President Johnson took deliberate steps to disguise the bombings of North Vietnam as reactions to attacks from North Vietnamese patrol boats, the press still found out about the fact of the matter, which was that Johnson was about to escalate the war. However, to the surprise of many working in the government, the approval of President Johnson and his decision to dramatically increase the US's participation in the Vietnam War, with Gallup Polls showing 85 percent of Americans supporting Johnson even following the event in the Gulf of Tonkin. While it was clear that the public approved of the fighting of this undeclared war, it seems like afterward, they gave the soldiers a negative image. In his analysis, Dean Jr. finds that the image of a scorned, pitiful, and helpless Vietnam veteran is largely just a perception created after the Vietnam war became such a nationally hated event. It was known that the modern and even past media has romanticized the view of a dishonored hero, who was blamed for losing the unpopular war, and then left out of the usual veteran benefits, which therefore led to the downward spiral in which Vietnam veterans fell into poverty, addiction, and mental illnesses such as PTSD and survivor's guilt, without the aid of any person. After all, the Vietnam soldier, after the events of the Mylai Massacre as well as 
the Tet Offensive, was seen as a weapon of mass destruction and represented everything wrong with the Vietnam War. However, Dean Jr. found that, based on the experiences of veterans from wars before and after the Vietnam war, veterans received a comparable amount of benefits and support from this war to any other war fought. It turns out that this perception from the war came only during the war, when a high appearance of PTSD and a mysterious "Agent Orange" caused a high amount of suicides within the ranks of the soldiers, and in fact, this led to a higher appreciation of the Vietnam Veteran as he came home, receiving parades and warm welcomes from the government, as a sort of repentance for sending them to face such pains.

One last theme that much of the research around war journalism in the present as well as in history fixates on is that of the experiences of the war journalists themselves, and the choices and experiences that led to their employment as war journalists. Through mostly interviews and oral histories, researchers have investigated the many experiences of war reporters and correspondents. One such researcher is Joachim J. Savelsberg who investigated the backgrounds of twelve war correspondents in Africa by interviewing them. From that research, he learned that many restraints in the habitus of the correspondent, including ethical and financial, hold back many correspondents from being able to report in full force. He also analyzed the many commonalities between a majority of the journalists, some of whom were from fairly middle class backgrounds, were mostly coming from the northern hemisphere, and were mostly males - factors which impacted the way they report wars and warfare. Investigations similar to these strove to understand the bringer of news as to make the consumption of such news more educated. However, even investigations of the journalist perspective during the many wars that are happening right now and the many more that have already happened are scarce to non-existent. There are some autobiographical accounts by these journalists that can also be relied on, such as that by Joseph Galloway, where he described his own experiences and his participation as a journalist during the Vietnam War. In this, he describes his opinions on a film based on a book he wrote on the Vietnam War, as well as his own experiences. Joseph Galloway also had a large part in writing a book about the battle of Ia Drang, one of the first major battles during the Vietnam War. In it, Joseph Galloway describes the events in gritty detail and the full involvement that even Galloway, the sole journalist, had in the battle. While the base of this writing may be tainted by pride and glorification of war, the events themselves and how heavily even the journalist had to fight for their lives gives an insight on how the war journalist truly works: in even the strongest heats of battle.

All of the literature found gives much insight on the many different facets of war journalism and the Vietnam War, with the many rules of war journalism being explained well throughout as well as the perceptions created by the war journalist of Vietnam to the American population. Some studies do talk about the war journalist, and many others talk about the soldier. However, nearly none, if not none at all, investigate the relationship between the soldier and the press. Even the perspective of the journalist is underdeveloped and under-researched, let alone the relationship between the war journalist and the soldier. While the literature does cover a wide variety of wars and perspectives, it does not nearly do enough to research this relationship, instead focusing on the more macro aspects of war journalism and the Vietnam War. This gap needs to be researched, and moving forward in a way some researchers in this literature have - using oral histories - may be the way to proceed. Within this study, the unique relationship between the press and the soldiers will be attempted as to bridge this gap. This will be limited to those veterans that were part of the United States Military during the Vietnam War, and how they were seemingly affected by the press and war reporting during that war. Specifically, this study acquired the personal perspectives of a number of these veterans through interviews.

\section{Methods}

In this study, I strove to answer the question of whether or not the embedded journalism in the Vietnam war affected the morale of American soldiers. With my readily available knowledge, I hypothesized that the press would have had a largely negative effect on the morale of the American soldier, making them fight an essentially futile war. With this question came a pretty significant assumption about the soldier. Asking the question of whether or not the morale of 
American soldiers was affected by war journalism assumes that soldiers had contact or a way of consuming war media and news media of the time.

\section{Surveys and Correlational Study}

To begin, I decided that I needed an overview on what the general population of American veterans of the Vietnam War was like, and whether or not they had much contact with journalists and journalism during the war. Due to the need for a general overview, I decided that a survey to would be the most apt method of collecting this data, similar to when the US Geological Survey was surveyed on their concerns under the Trump Administration which used questions that were more opinion based and qualitative to reveal large trends in the general population of those people. To recruit people to take the survey, I asked many friends if they had any relatives who served during the Vietnam War, as well as contacting Vietnam Veterans of America to ask for their assistance in finding people to survey. Questions from the survey were quite broad yes-or-no questions, with questions like "Did you come into contact with American journalists during your time in the war," and "In general, were you content with the involvement of the press during the war?" These questions would help me draw a broad picture on the demographic I would be looking at and would give me an understanding on the presence of journalism in the Vietnamese battlefront. I would then proceed to graphically display the results as to draw an understanding from a sample to see if the general consensus of Vietnam Veterans were similar in relations with journalists. This could very likely result in a homogenous field of similar results, or strikingly divisive answers to the same questions.

Of course, this form of data collection has its faults. This type of broad, simple survey would never be able to capture opinions and impacts that soldiers may have felt. This is because the questions are simple with yes or no as the only answer choices, as to allow for as many veterans as possible to take it, as any more complicated surveys may be daunting to take for anybody. Similarly, this survey would not be able to capture the qualitative aspects of the press's work and role in the war. This is why I decided to proceed with a form of qualitative data collection to continue investigating the topic.

\section{Qualitative Case Study}

In this study, I needed to collect qualitative information to understand the impacts of press on soldiers' morale, as morale is a very personal and subjective thing which may be impacted in different ways from person to person. Such a need resembles the research that Joachim Savelsberg conducted in "Rules of the Journalistic Game, Autonomy, and the Habitus of African Correspondents," in which he investigates the seemingly less-coveted work of war journalism in Africa through 11 interviews and an analysis of those interviews. Therefore, I decided that the best course of action would be to conduct a qualitative case study on Vietnam veterans at this time to understand the effects war journalism had on these veterans. To obtain qualitative data on how these soldiers perceived the press and if they were impacted in terms of morale, interviews seemed like the best course of action for understanding their viewpoints. This way, firsthand sources are used, as to understand in a more close and personal sense how soldiers particularly felt or maybe even how they feel now and how it has changed. Of course, this has the limitations of being highly reliant on the memories of people who held these opinions and experiences half a century before today. From the surveys, I had left a question asking if the person taking the survey would be willing to be interviewed, and a space to leave their contact information. I also contacted the Texas branch of Veterans of Foreign Wars, to which I received several more people who were willing to be interviewed. I would then reach out to the ones that were willing to do an interview, and over the course of 2 months, I conducted those interviews. During the interviews, I prefaced with questions that ask them about broader experiences that they had in Vietnam to understand the position they were in during this war, as well as to emotionally reintroduce their minds to the subject of the Vietnam War, which was so they did not feel emotionally shocked by the information that they may need to confront mentally before they can clearly think about the experiences that they had with the press. These questions would include simpler general questions like "How were 
your experiences in Vietnam in general?" and "Are some of the things that you saw back then impacting you now?" I then asked a number of questions that essentially ask them to consider the effects of embedded journalism and war journalism on the time they were a soldier during the Vietnam War. These questions would include those like "How do you feel about the journalists who were in the battlefield reporting on the war?" and "Did you interact with any war journalists or embedded journalists, and how did these experiences play out?"

To find more qualitative data on this matter, I looked through various interviews with Vietnam veterans during and after the Vietnam war, and focused on anything said about journalism, press, and any other sort of media, as well as their reaction and opinion on hearing and speaking on the subject. These sessions of interviews were used as supplements to the press focused interviews I conducts myself, and as extra qualitative data to build a stronger understanding on the impact of press on the American soldier. With those experiences recorded and their opinions on the press at the time, the important points transcribed onto paper, and their opinions on whether or not they were affected by the press, I proceeded to the next step of organizing all this qualitative information.

To better understand this qualitative data, I arranged their parts by theme, as to see what they overall try to convey, and understand the general message that the people I interviewed were trying to convey, as well as their opinions. To do this, I took the transcribed interviews and read through them to see if there are any recurring themes that would be important to describing the effect of the press on the soldier. With these themes written down, I analyzed how often these themes occurred, why they occurred, and with that, came out with a deeper understanding and analysis on how the war press affected the soldiers during wartime in Vietnam.

Understandably, there were also limitations to a method of data collection like this. Since I could only conduct a very limited number of interviews, the sample size limited the range of opinions that were recorded, which is why I decided to supplement the regular interviews with preexisting ones which could help provide a larger sample of ideas. Also, Rodney Earl Walton discusses this in his paper on interviews with veterans from World War II, where he found that soldiers "were frequently reticent about recounting their memories" of these wars and events due to the fact that these were very traumatic happenings for them. This caused an obvious obstacle for some interviews that revealed less than others. However, he also found "veterans' interviews were generally reliable and accurate" when they are able to be interviewed ${ }^{13}$. The thematic analysis portion of the method also contributes a few flaws. This method, being an efficient and organized but not particularly meticulous, contributed to more missed information as information that did not fit into any theme was passed over as not very relevant. 


\section{Results}

Did you come into contact with American journalists during your time in the war?

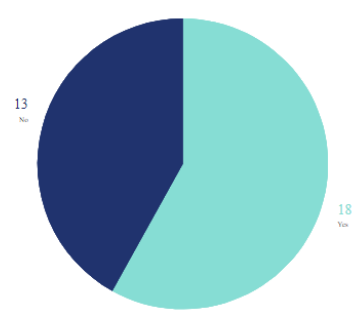

In general, were you content with the involvement of the press during the war?

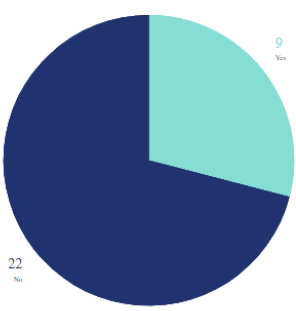

If you had an embedded journalist in your unit, were your interactions with them favorable?

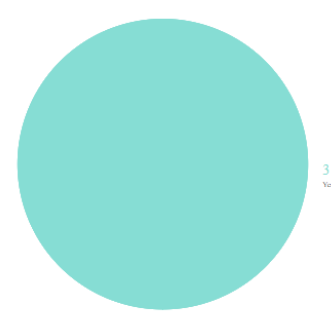

Was there a journalist embedded in your military unit (meaning staying with your military unit constantly, as if a part of that unit)?

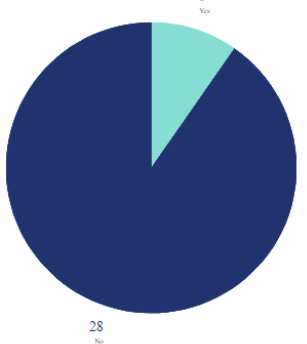

If you came into contact with journalists, were your experiences with them favorable?

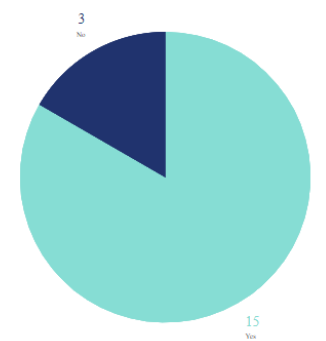

Do you believe your performance in the war was affected by these journalists?

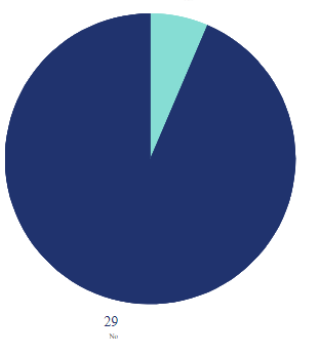

Do you believe your performance in the war was affected by the press in general?

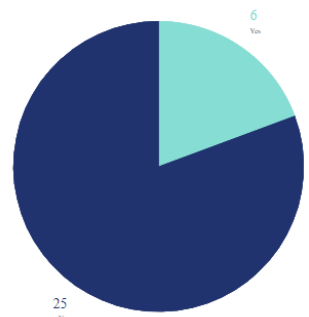

Figure 1. Pie charts representing the responses of survey-takers, with the lighter portion being an affirmative answer and the darker portion being a negative answer. 
Table 1. Results - Interview Categorization

\begin{tabular}{|l|c|}
\hline \multicolumn{1}{|c|}{ THEME } & \# EXPRESSING SENTIMENT \\
\hline 1.Journalists in Vietnam were good people & 3 \\
\hline $\begin{array}{l}\text { 2.Early in the war, press is more popular or relatively } \\
\text { unknown }\end{array}$ & 2 \\
\hline $\begin{array}{l}\text { 3.Anger that civilian press caused undue abuse of } \\
\text { veterans }\end{array}$ & 2 \\
\hline $\begin{array}{l}\text { 4.Used Stars and Stripes as a news source and knew } \\
\text { about its biases }\end{array}$ & 3 \\
\hline 5.Did not feel the press affected their performance & 2 \\
\hline
\end{tabular}

\section{Analysis}

The Vietnam veterans surveyed seemed to have similar views on the journalism that happened in the Vietnam War. Out of 31 surveyed, 18 veterans, more than half, came in contact with an American journalist, which is not too surprising, as the civilian press, with the new presence of television journalism, would have a much higher demand for filmed and processed materials that couldn't be covered by just a few journalists with notepads and pens that older wars would see fit. There seemed to be a lot fewer embedded journalists among those I surveyed, which may just be due to the fact these reporters would be on military payroll and there was only one military newspaper, the Stars and Stripes, causing the US Military to not invest too much into embedded press. This could also be due to the fact that "the press was allowed unprecedented access, due largely to the growth of television as a popular mainstream medium for prime-time news," and so the proportion of reporters noticed and interacted with by soldiers may have been heavily weighted towards civilian press. As expected, the veterans were not in favor with the negative press that occurred during the war. However, it is most likely that this large amount of negativity towards the press is retrospective, as most of those interviewed mentioned not feeling the effects of negative civilian press until they made it back to their homes, as seen in theme 3. For both the interactions with the civilian and military journalists, the veterans responded that the interactions were overwhelmingly favorable, which is also reflected in the responses of the interviews, showing a sense of respect between the soldiers and the individual journalists present in the battlefields of Vietnam. Responding to the last questions on whether individual journalists or the press in general impacted the result of the overall war in Vietnam, there was an overwhelming answer of no, which reflects the sense of military pride and patriotism instilled in all soldiers during training, and also seems to show that the morale was in general unaffected by the journalism that happened.

To really understand why these soldiers responded in the way they did, though, I needed more in-depth explanations, which come in an analysis of the themes identified throughout the interviews. One theme that occurred commonly was the theme of believing that the journalists in Vietnam were good people. This seemed to occur throughout the war, with a sense of respect between the soldiers and the journalists in the people I interviewed as well as the interviews I looked at, while only one person I interviewed had a negative feeling towards a journalist. One big factor in this feeling is probably the mutual sense of respect that soldiers felt for other people on the battlefield. As stated by the stars and stripes, these soldiers saw the journalists as nothing more than fellow men who would usually "wore uniforms, ate field rations and shared the many dangers and deprivations of normal fighting men." This probably fostered a relationship of respect, if not outright comradery. 
Another significant theme is the soldiers' common use of Stars and Stripes as their news source, and the understanding of the biases of that news as well as other civilian news sources. Henri Boucher, a veteran I interviewed, put it as 'two diametrically opposed views coming at you, and you say, 'What the heck is the real story here?' ... [he] was in communications, so [he] knew factually what was occurring, and it was some place in between both ends of the spectrum." It is clear that, due to actively experiencing the events that were portrayed in the paper, the soldiers would start to doubt the press the second they heard of an event they participated in being portrayed in any exaggerated way from how they remember it, whether the losses or gains be overexaggerated or understated. Many of these soldiers, as Boucher said, "looked at it kind of like ... 'Hey, do you see this? Do you remember it like that? No.' So kind of like a joke."

Some smaller themes that only came up twice include the less common occurrence of press in the earlier years of the war, the anger at the civilian press for causing the undue harm towards the image of the American soldier in Vietnam, and the feeling that the press did not have an effect on the morale and performance of the soldiers at all. The lower amounts of press in the early years of the war can be explained by the newsworthiness of the war before the escalation of the Vietnam War in 1965, where the troops in Vietnam increased to the point that there were 189,000 troops stationed in Vietnam by the end of 1965 and along with them hundreds of journalists. The anger towards civilian press post-war was a very significant factor historically, as it would bring a decade of scorn upon the Vietnam veteran, but it did not affect the morale of the soldier during the war, so it was not relevant to this subject. Lastly, the belief that the press did not influence morale is only specifically mentioned by two people, which is only due to the fact that I only interviewed a few people and the filmed interviews did not focus on this factor specifically. However, I believe that if more veterans were asked, they would hold a similar sentiment, as the survey results would show. This is probably due to the classic military pride that is instilled into every soldier during training and out in the field, as well as the same cynicism of the press that I described in theme 4.

\section{Conclusion}

The results of this research and an analysis of the common themes show how the veterans of Vietnam actually felt about the media presence in Vietnam. It appears that the press had near no effect on the morale of soldiers in Vietnam, with the soldiers themselves not describing any sense of change or any effect on performance due to any bad press, mostly pushing it aside as nothing more than an opinionated media, whether that be from the civilian press or the army itself. While this does show quite a contrast from the effect on the morale of citizens at home in the United States seen in the literature, it is quite understandable as soldiers did have a much more immediate way of learning about the war, and would not trust or be affected by any media that described something they didn't see themselves.

However, due to the retrospective nature of this research, it is very possible there was some bias in the process. The veterans' pride may have affected the answers in a way that did not reflect their true experiences. This may have led to the veterans going ahead with the idea that they were steadfast in the message of freedom that their army and their country so widely advertised, even if their morale may have been damaged by the press. The small amount of people who were interviewed was very likely insufficient to get a true understanding of their situations. The best way to proceed would be to gather a larger sample of veterans to interview and survey on this war specifically, but also an expansion to other wars, such as the wars in the Middle East, where embedded press was introduced and bad press from the war became a less common occurrence. An understanding of this relationship between the press and the soldier allows for an analysis of the role of the press in wars past and present, as well as an understanding of how the government controls press from war to war. The relationships between the different parts of warfare allows for a clearer and more vivid image to be formed, as well as an understanding of how culture that the war arises from effects its goals in the end. 


\section{References}

Dean, Eric T. "The Myth of the Troubled and Scorned Vietnam Veteran.” Journal of American Studies 26, no. 1 (1992): 59-74. https://doi.org/10.1017/s0021875800030218.

Delli Carpini, M. X. (1990). Vietnam and the press. In D. M. Shafer (Ed.), Legacy: The Vietnam War in the American imagination (pp.125-156). Boston, MA: Beacon Press.

McLaughlin, Greg. "Journalism, Objectivity and War." In The War Correspondent, 33-62. London: Pluto Press, 2016. http://www.jstor.org/stable/j.ctt19qgf0x.7.

“Office of Academic Affiliations.” Go to VA.gov, June 16, 2009. https://www.va.gov/oaa/pocketcard/vietnam.asp.

Paul, Christopher, and James J. Kim. "History of Relations Between the Press and the Military." In Reporters on the Battlefield: The Embedded Press System in Historical Context, 35-62. Santa Monica, CA; Arlington, VA; Pittsburgh, PA: RAND Corporation, 2004. Accessed May 13, 2020. www.jstor.org/stable/10.7249/mg200rc.10.

Proctor, Pat. "Message versus Perception during the Americanization of the Vietnam War." Historian 73, no. 1 (2011): 88-112. https://doi.org/10.1111/j.1540-6563.2010.00287.x.

Proffitt, Nicholas. "Pride and Anguish: WE WERE SOLDIERS ONCE . . . AND YOUNG La Drang: The Battle that Changed the War in Vietnam. by Harold G. Moore and Joseph L. Galloway. Illustrated. 412 Pp. New York: Random House. \$25. Pride and Anguish." New York Times (1923-Current File), Nov 08, 1992. https://search.proquest.com/docview/108992730?accountid=5682

Robson, Seth. "War Stories: Vietnam War Journalists Share Examples of Courage.” Stars and Stripes, October 31 , 2017. https://www.stripes.com/news/special-reports/vietnam-stories/1967/war-stories-vietnam-war-journalistsshare-examples-of-courage-1.495465.

Savelsberg, Joachim J. "Rules of the Journalistic Game, Autonomy, and the Habitus of Africa Correspondents." In Representing Mass Violence: Conflicting Responses to Human Rights Violations in Darfur, 205-21. Oakland, California: University of California Press, 2015.

Sparre, Kirsten. "Conceptualising Changes in War Reporting." Sicherheit Und Frieden (S F) / Security and Peace 18, no. 3 (2000): 252-58. http://www.jstor.org/stable/24231190.

Spector, Ronald H. "The Vietnam War and the Media.” Encyclopædia Britannica. Encyclopædia Britannica, inc. Accessed October 12, 2019. https://www.britannica.com/topic/The-Vietnam-War-and-the-media-2051426.

Stahl, Norman A., Jennifer C. Theriault, and Sonya L. Armstrong. "Four Decades of JDE Interviews: A Historical Content Analysis." Journal of Developmental Education 40, no. 1 (2016): 4-16. Accessed January 22, 2020. www.jstor.org/stable/44987720.

Steinman, Ronald. "The First Televised War." The New York Times. The New York Times, April 8, 2017. https:/www.nytimes.com/2017/04/07/opinion/the-first-televised-war.html. 
Union of Concerned Scientists. Report. Union of Concerned Scientists, 2018. Accessed May 21, 2020. doi:10.2307/resrep24148.

Walton, Rodney Earl. "Memories from the Edge of the Abyss: Evaluating the Oral Accounts of World War II Veterans." The Oral History Review 37, no. 1 (2010): 18-34. Accessed February 18, 2020. www.jstor.org/stable/41440758.

"Years of Escalation: 1965-68." ushistory.org. Independence Hall Association. Accessed May 13, 2020. https://www.ushistory.org/us/55b.asp. 